\title{
Efficiency concept and investigations in insurance industry: A survey
}

\author{
Bilel Jarraya ${ }^{a^{*}}$ and Abdelfatteh Bouri ${ }^{\mathrm{b}}$ \\ ${ }^{a}$ Ph D Student at the Faculty of Economics and Management, FSEGS, Sfax University, Tunisia. Unit of Research Corporate Finance and Financial \\ Theory \\ ${ }^{b}$ Professor of Finance at the Faculty of Economics and Management, FSEGS, Sfax University, Tunisia. Unit of Research Corporate Finance and
} Financial Theory

\section{H R O N I C L E}

Article history:

Received June 2, 2012

Received in revised format

28 October 2012

Accepted 7 November 2012

Available online

November 92012

Keywords:

$X$-Efficiency

Technical efficiency

Allocative efficiency

Inputs-Outputs

Parametric approach

Non-Parametric approach

Field investigations

\begin{abstract}
A B S T R A C T
Most recent studies are based on benchmarking analysis allowing the measure of company efficiency relatively to a reference performance. Benchmarking is a helpful tool to analyze and promote efficiency in insurance companies. The fast development of X-efficiency notion makes traditional performance measures (ROA, ROE, etc.) obsolete. Indeed, various methods have been used, various input-output measures have been proposed and various research fields have been explored in insurance company investigation. So, after reviewing most known efficiency concepts and their definitions, this section explores the literature review of two principal points of discussion: the first point is focused on the different used techniques to measure efficiency, including the developed approaches to define inputs, outputs and their prices. The second point represents an overview of efficiency investigations in insurance industry.
\end{abstract}

(c) 2013 Growing Science Ltd. All rights reserved.

\section{Introduction}

Be effective is a key objective for all companies guaranteeing its survival. The choice of technique and variables (inputs and outputs) has an important effect on efficiency measurement and consequently that will influence the decision makers and the development of strategic plan. With the fast development of X-efficiency notion, the traditional performance measures became obsolete. Indeed efficiency frontier methods are more objective than the financial ratios as Return On Equity (ROE) and Return On Assets (ROA) that are extensively used to measure company performance. These traditional methods allow only the assessment of a mean function whereas the goal of efficiency frontier methods is to evaluate the distance between each observation and an estimated frontier. Two main approaches to measure efficiency: the first is the parametric approach, also called econometric approach, in which most used methods are: Stochastic Frontier Approach (SFA); Tick 
Frontier Approach (TFA) and Distribution Free Approach (DFA). The Second is the nonparametric approach, also called mathematical programming approach, and it include two principal methods: Data Envelopment Analyses (DEA) and Free Disposal Hull (FDH). These two approaches aim to specify a frontier shared by all companies of the studied sample. Thus, all companies share a similar mode of production and their respective performances are compared to the same frontier (production, cost or profit). Indeed this section is organized as follows: we devote the first part to present the efficiency concept. In the second sub-section we investigate different techniques developed in the literature to estimate the frontier and measure efficiency. Finally, the last sub-section represents an overview of efficiency investigations in insurance industry.

\section{Efficiency concept}

Koopmans (1951) and Debreu (1951) are the pioneers of efficiency concept. Koopmans is the first who proposes a measure of efficiency concept and Debreu the first who empirically evaluates efficiency. Debreu proposes the use of a resources coefficient expressed by the input-output ratio. Farell (1957) is the first who shows that productive or economic efficiency can be divided in two components. The first one is the purely technical component, which refers to the ability of a production unit to produce the maximum output quantity. So the technical efficiency component aims to increase outputs and avoid the maximum of wastes. The measure of technical efficiency is usually defined as the maximum reduction of all inputs allowing continual production of the same output as before. The second one is the price component also called allocative efficiency. This component refers to the capacity of the production unit to mix optimal proportions of inputs and outputs appropriate to their current prices (Griffel Tatjé \& Lovell (1997)). In the literature there are three principal efficiency aspects can be defined: Scale economies, scope economies, and X-efficiency.

\subsection{Scale Efficiency}

In a consolidation context and with the growing number of mergers and acquisitions the research works are focused on scale economies studies in financial institutions, especially for insurance companies (Cummins and Weiss (2000)). Despite differences in the contexts, the used methods and the studied periods between different studies in this research area, most of them have shown the increasing of scale economies (Fecher et al., 1991; Hardwick, 1997; Hwang \& Gao, 2005). Thus, differentiation between size clusters has an important role to reach more specific and more meaningful results. Yuengert (1993) uses a sample of 765 USA's insurance companies in 1989. He finds a constant return for bigger insurance companies and increasing return to scale for life insurance companies having less than US\$15 billion of assets. however, Cummins and Zi (1998) using a sample of 445 life insurance companies over the period 1988-1992, they find that firms having less than US $\$ 1$ billion of assets are characterized by an increasing return to scale, and decreasing return to scale for most other firms.

\subsection{Scope Efficiency}

The scope economies' level is measured while basing on the percentage change of production costs between specialized firms and non-specialized firms (i.e. multi-product or multi-brunch firms). So, a positive rate indicates the existence of scope economies and non-specialized firms are more efficient than specialized firms. Otherwise, the specialized firms are the most efficient and in this case there exists scope diseconomies. The well known problem of this method is the data availability. The growing number of mergers and acquisitions between insurance companies from different lines of business pushes researchers to investigate the existence of scope economies in this industry. In this context, most studies show the existence of scope economies and conclude that non-specialized insurance companies are more efficient than specialized companies (Meador et al., 2000; Fuentes et al., 2005; Cummins et al., 2007). Berger et al. (2000) use a sample of 684 USA's insurance companies 
over the period 1988-1992. They show that larger firms are more suitable to realize profit scope economies.

\section{$2.3 X$-Efficiency}

The productive efficiency or X-efficiency concept has been firstly developed by Leibenstein (1966). He investigates the measures of firms' productivity focusing on the used quantities of inputs to create the maximum of outputs. The author suggests that, if all firms of an industry produce the same scale and combination of outputs minimizing the average production cost, then the total producing cost of the industry is minimized. So, an industry produces the efficient level and combinations of products if each firm uses efficiently its inputs. The X-inefficiency could be due to technical inefficiency or allocative inefficiency.

$\checkmark$ Technical inefficiency: This concept is defined as the company capacity to produce the maximum of outputs constrained by a given level of inputs. So the technical efficiency represents the difference between the real production level achieved by the company and the ideal output level at the frontier. Most studies refer to the study of Farell (1957) to measure technical efficiency.

$\checkmark$ Allocative inefficiency: a firm is considered allocatively efficient when it uses the optimal combination of inputs for given input prices and outputs' quantities. Referring to Cummins and Xie (2008), this efficiency concept allows finding either the optimal combination of inputs that minimizes cost, either the optimal combination of outputs that maximizes revenue. This efficiency concept is useful to see whether a firm produces outputs with the optimal quantities of inputs. In addition it allows to find firms that over/under-use their capital.

Recently, research works that investigate performance in financial institutions has increasingly focused on X-efficiency. This measure allows finding the distance between the present place of a firm and a predefined frontier that represents best practice firms. So, the X-efficiency measures the performance degree a firm referring to best firms in the same industry and with the same market conditions. To measure efficiency we must specify an objective function. There are four key functions can be defined as a reference to measure efficiency: production, cost, revenue and profit function. These functions represent an economic foundation for studying firms' efficiency. therefore, they allows to make some economic optimizations while taking account of market prices, competition and other business conditions, rather than being based exclusively on using technology.

\subsection{Revenue Function}

Revenue efficiency is generally measured using an output distance function. This function allows determining, for the same period and the same exogenous factors, the most efficient firms in producing an output bundle. So, a firm attains revenue efficiency if it produces the optimal mix of output and employs the best practice technology. Firms could attain revenue efficiency when they charge higher prices for higher quality services. So, these firms can take advantages from some opportunities of consumer surplus. Berger et al. (1996) show that revenue inefficiency is mainly attributed to technical inefficiency than allocative inefficiency. DeYoung and Nolle (1996) suggest that the main drawback in using this function is the ignorance of production costs of higher quality services provided by financial institutions. Several research works study revenue efficiency in insurance industry such as: Berger et al. (2000), Ward (2002), Choi and Weiss (2005), Choi and Weiss (2008), and Cummins and Xie (2008).

\subsection{Cost Function}

Cost function is useful to seek the minimum cost needed to produce a given output bundle. A firm is considered costly efficient if it achieves the lowest product costs in a sample characterized by the same exogenous variables (input prices, variable output quantities and fixed net puts. Most studies use the ratio of lowest estimated cost divided by actual expended costs to define cost efficiency. This 
ratio fluctuates from 0 to 1 , more it is higher more the firm is efficient. Ikhide (2000) shows that extraordinary factors affect more significantly revenue and profit than cost efficiency. Several research works investigate cost efficiency in insurance industry (Fecher et al., 1991; Gardner \& Grace, 1993; Berger et al., 1997; Cummins, 1999; Berger et al., 2000; Cummins \& Nini, 2002; Greene \& Segal, 2004; Choi \& Weiss, 2005; Hao \& Chou, 2005; Cummins et al., 2006; Hao, 2007; Bikker \& van Leuvensteijn, 2008; Choi \& Weiss, 2008; Fenn et al., 2008). In using cost efficiency, researchers assume that output is constant at its current quantity, but generally this level of output doesn't an optimum. So this function allows investigating efficiency corresponding to the current output quantity but not to the optimal output level.

\subsection{Profit Function}

Revenue function and cost function allow only maximizing revenue or minimizing cost respectively. However, these two perspectives fail to find the firm's goal to maximize profit. Previous researches develop two main approaches to study profit efficiency: Standard Profit Efficiency and Alternative Profit efficiency.

\subsection{Standard Profit Efficiency}

Standard profit efficiency measures the firm's capacity to achieve the maximum profit given particular levels of inputs prices, outputs prices, fixed net-puts quantities and environmental variables. Contrary to cost function, the standard profit function is based on variable profits and given variable output prices rather than using variable costs, rather than using variable costs and fixed output quantities at their observed levels (which is usually inefficient). So, independant variables in profit function allow achieving the best revenues that can be earned while varying inputs as well as output quantities. Berger and Mester (1997) show that profit efficiency is the most comprehensive measure of performance than cost efficiency, because it takes consideration of errors on output side as well as on input side.

\subsection{Alternative Profit efficiency}

Alternative profit efficiency assesses change in firm's variable profits adjusted for random error. This adjustment is relative to the estimated variable profit needed to produce optimal output as efficiently as the best practice firm in the sample. Efficiency changes are attributed essentially to management efforts and environmental variables. This function is based on the same dependent variable as the standard profit function and the same exogenous variables of the cost function. The alternative profit function differs from standard profit function in using variable output quantities than variable output prices. Several research works investigate profit efficiency in insurance industry (Berger et al., 1997; Berger et al., 2000; Ward, 2002; Klumpes, 2004; Yuan \& Phillips, 2008).

\subsection{Directional Output Distance Function}

Radial distance functions have been originally introduced by Shephard $(1953,1974)$. These functions have been widely used in empirical work as a representation of a firm's technology. Färe and Primont (1995) present a summary of Shephard's papers. In recent developments, Luenberger $(1992,1995)$ propose new functions called the shortage and the benefit functions. Based on these functions Chambers et al. $(1996,1998)$ pioneer directional distance functions.

The presence of undesirable output in production process represents a big problem for researchers. So, desirable outputs are eventually marketable goods, while undesirable outputs are inevitable products having negative effects on the firm's profitability or on the whole environment. Traditional investigation in production theory doesn't study good and bad outputs in the same production model. Recently, research works are increasingly interested to this research field. Based on the traditional efficiency analysis of Farrell (1957), Färe et al. (1989) develop efficiency measures including undesirable outputs in the production process. more recently, Chung et al. (1997) extend the Shephard's output distance function Shephard (1970) by representing a joint production of desirable 
and undesirable outputs called the directional output distance function. So, this function has for role to seek simultaneously the maximum expansion and contraction of desirable and undesirable output, respectively. Chambers et al. (1996) and Chambers et al. (1998) show that the directional technology distance function generalizes the radial (input and output) distance functions and allows a suitable tool to study environmental and economic performance.

\section{How to Measure Efficiency}

The efficiency measurement concept reflects the company performance measured relatively to a prespecified frontier also called "best practice" frontier. This frontier is defined through the most efficient firms in the sample. Two key approaches are used to measure efficiency. The first is named parametric approach of which more used methods are: Stochastic Frontier Approach (SFA); Thick Frontier Approach (TFA) and Distribution Free Approach (DFA). The second is the nonparametric approach whose most known methods are: Data Envelopment Analyses (DEA) and Free Disposal Hull (FDH). However, before starting the theoretical exploration of these techniques, we will present, in a first time, the different proposed approaches to specify inputs and outputs.

\subsection{Input-Output Specification Approaches}

The definition of inputs, outputs and their corresponding prices has a key role in efficiency investigations. A poor definition of these quantities can lead to non-significant or erroneous results. This problem is more serious in the service sector especially in the insurance industry, where some quantities are intangible, implicit or not available. So, several works researches try to find the most suitable definitions of inputs, outputs and their prices. In follows we will present some theoretical discussion.

\subsubsection{Inputs and Inputs’ Prices}

\section{Inputs Specification}

Researchers usually subdivide inputs into three principal categories: business services and materials, capital and labor. Contrary to capital and labor categories, most studies doesn't subdivide business services and materials into subcategory. Labor category involves two principal sub-categories such as: agent labor and all other labor called home office. This subdivision is mainly due to the difference in price between the two sub-categories and the proportion allocated for each sub-category by the firm. This proportion differences is related to the marketing type adopted by the insurance company: direct or indirect. However, capital category contains three types: equity capital, debt capital and physical capital. In empirical evidences, several studies use the operating expenses as an input that represents labor and business services and materials (Diacon et al., 2002; Fenn et al., 2008); Eling \& Luhnen, 2010; etc.). The principal cause of this simplification is the unavailability of some data such as the employees' number and the number of worked hours. In addition, from an econometrical point of view this simplification reduces the parameters' number that must be estimated (Ennsfellner et al., 2004). Most studies consider that the majority of operating expenses in insurance industry are due to commissions and employees' salaries and the remainder is considered as the physical capital presented by the business services and materials (Elign \& Luhnen, 2010; Cummins \& Weiss, 2000). Many research works consider the equity capital as an imperative input (Hughes \& Mester, 1998; Cummins \& Weiss, 2000; Eling \& Luhnen, 2009). This input has for role to ensure claims payment and regulatory requirement when losses exceed expectation. To calculate this input Cummins and Xie (2008) propose to calculate, for each insurance company, the annual average of equity capital and deflating it by the Consumer Price Index (CPI). The best evaluation of equity capital is that of expected market return to cost equity, but most insurance companies are not listed on stock market.

Similarly to the deposits in banks studies, debt capital is considered as an input in efficiency studies on insurance companies. For financing some of their investment the insurance companies seek to enhance debt capital. So, they submit some of their annuity and insurance policies Cummins and 
Weiss (2000). Ennsfellner et al. (2004), Cummins et al. (2004) and Fenn et al. (2008) propose technical provisions as another input that takes account of both loss and unearned premium reserves.

\subsubsection{Inputs’ Prices}

When researchers use cost function or profit function to investigate efficiency, they must necessarily specify the price of each input. Although operating expenses includes labor and business services, most studies use only the labor prices, also called wage variable, as the price of operating expenses as whole. This suggestion is explained by the dominance of employee salaries and commissions on operating expenses for insurance industry (Fenn et al., 2008; Elign \& Luhnen, 2010). This variable can be obtained from different national or international statistical institutes, such as: the International Labor Organization (ILO), Eurostat, the Instituto Nacional de Estadística (INE) in Spain, Institut national de la statistique et des études économiques (INSEE) in France, U.S. Department of Labor (DOL), etc. The well known approach to measure the price or the cost of equity capital is the return on equity based on market value. Nevertheless most insurers are not publicly traded so used sample size will be restricted. For this reason, other studies propose to use ROE based on book value net income divided by policyholders' surplus for some years prior the investigated period. Many drawbacks are dressed to the use of the ROE ratio. First, the use of this ratio reduces the number of years in which efficiency can be investigated. Second, the calculated ROE ratio can be negative, whereas it must be positive to be used in the remainder of the efficiency study. To overcome these problems, some studies use the yearly total return rate corresponding to the stock exchange index of each country (Elign \& Luhnen, 2010). There is no consensus on the definition of the debt capital price but the most used proxy of this variable is the one-year treasury-bill rates that can be extracted from different national and international statistical institute (Fenn et al., 2008; Elign \& Luhnen, 2010).

\subsection{Outputs and Output Prices}

\subsubsection{Outputs Specification}

In existing studies of insurance companies' efficiency we find three principal approaches to define outputs: the intermediation approach, the user cost method and the value added approach.

$\checkmark$ The intermediation approach: In this approach the insurance company is considered as a financial intermediary (Brocket et al., 1998). Therefore, it borrows funds from policyholders transforming them en assets, essentially by paying out claims, investing in capital market... The main objective of this approach is to maximize simultaneously the value of claims' ownership and capital return adjusted to risk. But insurance companies offer other services in addition to financial intermediation. Ignoring these other functions allocated to the insurance company leads to erroneous results in efficiency studies.

The user cost method: This approach aims to classify financial product as an input or output basing on its net contribution to the firm's revenues (Hancock (1985), Cummins and Weiss (2000)). So if an asset's return (or a liability's cost) exceed (is less than) its cost opportunity then the product is considered as an output, else it is considered as an input. At the theoretical level, this approach is the most ideal, but at a practical level, it is almost impossible to find the necessary data.

$\checkmark$ The value added approach: this is the most used approach for studying insurance companies' efficiency. An asset or a liability is considered as an output if it has a meaningful added value based on operating cost allocations. The remainder of assets and liabilities are considered as inputs, intermediate product, or unimportant outputs while taking account of considered activity (Berger et al., 2000).

Most outputs of financial institutions, particularly of insurance companies, are intangible. From a theoretical perspective, researchers distinguish three main services provided by insurance companies: 
$\checkmark \quad$ Risk-pooling and risk-bearing: Through pooling mechanism, insurance company provides a risk reduction service for insurable contingencies of businesses and consumers. A great part of collected premiums are redistributed by the insurer to policyholders who face losses. The value added in insurance is composed essentially by the underwriting, actuarial and linked expenses to the risk pool activities. So, the reduced risk is supported by other stakeholders such as: shareholders for stock companies, previous policyholders for mutual organizations and other actors holding the insurance company's debt. So, this will increase economic security and allows creation of value added.

$\checkmark$ "Real" financial services relating to insured losses: A wide variety of real services are provided by the insurance company for policyholders. In non-life insurance companies these services contain essentially investigations carried out by the company to recognize unusual loss exposures and the developed programs to cover risks. Some loss prevention services are provided by the insurance company such as programs related to the employment injuries. In life insurance companies, real services include essentially financial planning for individuals and benefit plan administration for other businesses. Policyholders can profit from specialized expertise and extensive experience of insurance companies to minimize costs linked with insurable risks.

$\checkmark \quad$ Intermediation: Insurers collect funds from annuities and insurance policies and invest them until they are removed by policyholders or used to reward claims. Investment incomes are directly contributed to policyholders' accounts in life insurance companies. However, in non-life insurance companies policyholders pays premiums with discount to recompense funds opportunity cost, similarly to interest payment in life insurance companies. Insurers invest collected funds principally in marketable assets. The intermediation process allows insurance company to invest in some inaccessible assets to the public such as privately placed bonds. The value added of the intermediation process is the interest margin between return earned rate on assets and provided rate to policyholders.

\subsubsection{Outputs’ Prices}

The output price definition is directly related to the proxy choice of output amount. Most recent insurance literature (Berger, Demsetz, and Strahan (1999); Cummins and Weiss, (2000)) use the value added approach.

Some studies use premiums as an output proxy (Yuengert (1993), Gardner and Grace (1993), Fecher et al. (1993)) and they classify the net premium as the value added for customers. In contrast Commins and Wiss (2000) propose the incurred benefits and the changes in reserves as a proxy of output for life insurance companies. They divide this output in five major variables: accident and health insurance, individual annuities, group annuities, individual life insurance and group life insurance. Cummins, Weiss and Zi (2003) define the price of each output variables as follows: they subtract the output for the line from the sum of investment income and premiums divided by output.

For non-life insurance companies, Berger et al. (1997) and Cummins and Weiss (2000) use losses incurred as an output proxy. This proxy represents the total expected losses amount that must be distributed by the insurance company as a consequence of providing insurance coverage for a given time period. These research works define the investment income as a proxy of the intermediation output. The insurance output price is the earned premiums less the present value of losses incurred the whole divided by the last variable. However, the intermediation output price is defined by the expected return rate on insurance company assets. Return rates of the boiled portfolio by the company are defined as a weighted average of equity returns and the debt.

\subsection{Efficiency Measures}

Despite intense research efforts, there is no consensus on the best method to measure the efficiency frontier. The choice of any method has a great effect on the expected results and that can influence 
negatively on the decision of the manager. In the last twenty years, five key methods have been developed to assess firm performance referring to a defined or estimated benchmark. There are two non parametric methods, the first is Data Envelopment Analyses (DEA) and the second is Free Disposable Hull (FDH). We find also three parametric econometric methods: the Stochastic Frontier Approach (SFA), the Tick Frontier Approach (TFA), and the Distribution Free Approach (DFA). The imposed assumptions to build the efficient frontier, on the parametric methods, differ from a method to another. These differences reside essentially on the existence of a random error and the imposed assumptions to distinguish the efficient term from the error term.

\subsubsection{Non-Parametric Approach}

Non-parametric methods impose few restrictions for building the X-efficiency frontier. They include the data envelopment analysis (DEA) and free disposable hull (FDH).

\section{Data Envelopment Analysis (DEA)}

Based on the search paper of Farrell (1957), Charnes et al. (1978) have proposed the DEA method. This is a linear programming technique that examines, from a given sample, how operates a decision making unit compared to other units. This method aims, in a first step, to build a frontier from efficient decision making unit. In the second step, an efficiency score is calculated for each decision making unit placed below the boiled frontier. These scores are belong $[0,1]$, the efficient decision making unit are placed at the frontier and their scores is equal to 1. Several research works have used this method to investigate efficiency in the insurance industry (Cummins et al., 1996; Brockett et al., 1998; Carr et al., 1999; Cummins, 1999; Barros et al., 2005; Yao et al., 2007).

\section{Free Disposable Hull (FDH)}

Deprins et al. (1984) are the pioneers of this nonparametric method. In this context, one can classify the producers' efficiency by making a comparison between individuals' performances referring to the production possibility frontier. For a given level of input, one can observe the highest possible level of output/outcome along this production possibility frontier. Conversely, one can determine the lowest necessary level of input to achieve a given level of output. The FDH is characterized by its parsimonious approach in building the production frontier. This method doesn't depend neither on a previous specification of the production function nor on any restriction imposed to the frontier shape. The best-known application of this method in the insurance sector is led by Cummins and Zi (1998).

\subsubsection{Parametric Approaches}

This approach is characterized by a functional form pre-specification to estimate efficiency frontier (Casu \& Molyneaux, 2003). They include the thick frontier approach (TFA), stochastic frontier approach (SFA) and the distribution-free approach (DFA).

\section{Tick Frontier Approach (TFA)}

This method is a distribution free way to estimate cost frontier based on panel data. The Thick Frontier Approach is developed by Berger and Humphrey (1992) and applied in banking sector. In a first step, we sort data on the average costs. In a second step, two thick-frontiers must be estimated. One for the lowest average cost quartile of firms and the other for the highest average costs quartile of firms. In third step, one independently executes these estimated frontiers for each year in the sample. Finally, based on a comparison of the two tick frontiers, one calculates the average inefficiency of the highest quartile firms. This method is useful for regulatory conclusions since it only allows the estimation of average efficiency scores. Berger et al. (2000) and Yuengert (1993) use the Tick Frontier Approach to estimate efficiency in USA insurance industry. 


\section{Distribution Free Approach (DFA)}

This method aims to estimate the efficiency score of each firm using a functional form of the frontier. Estimated scores of this firm are used to compare its average residual to the average residual of the best practice firm at the frontier. However, the stability of relative efficiencies across firms is not usually realizable (Berger \& Humphrey, 1997). Therefore, this method requires fewer hypotheses, but needs several data years. The drawback of this method is that assumes efficiency of each firm is unchangeable, only the random error term is different from zero. Several studies use this method to investigate efficiency in the insurance industry (Ryan \& Schellhorn, 2000; Meador et al., 2000).

\section{Stochastic Frontier Approach (SFA)}

The SFA is an econometric approach based on the quantitative economy theory. Aigner et al. (1977) and Meeusen and van den Broeck (1977) separately develop a random error structure of frontier analysis to measure firm's efficiency. This method aims to decompose the error term on two components. The first component represents the inefficiency term and it is assumed to be half normally distributed. The second component is the error term that follows a symmetric distribution (also called standard normal distribution). This method ensures that efficiency term is non-negative. Several studies apply this approach in the insurance industry (Cummins \& Weiss, 1993; Yuengert, 1993; Toivanen, 1997; Berger et al., 2000; Chaffai \& Ouertani, 2002; Ward, 2002; Ennsfellner et al., 2004).

\section{Overview of Efficiency Investigations in Insurance Industry}

Recent research works are more and more oriented towards studies focused on the efficiency measurement. Particularly, the insurance industry captures a growing number of investigations based on frontier efficiency techniques. This subsection presents an exploration of several studies focused on insurers' efficiency in different research fields: Agent Distribution Systems, Capital Exploitation and Financial Risk Management, General level of efficiency and evolution over time, Across-Country Comparisons, Market Structure, Mergers and Acquisitions, Corporate Governance and Organizational Forms, Regulation issues...

\subsection{Agent Distribution Systems}

Several studies show that direct distribution systems (employed agent or company representatives) are less efficient than independent agent distribution systems (Brockett et al., 1998, 2004; Klumpes , 2004). In another study, conducted by Berger et al. (1997), the direct distribution systems are more cost efficient, however the two distribution systems are equally efficient while taking account of profit. For the combining systems problem, Ward (2002) concludes that insurers using more than one mode of distribution system are less efficient than those employing only one distribution system.

\subsection{Capital Exploitation and Financial Risk Management}

At the beginning, several studies investigate implicitly in this search field. Cummins and Nini (2002) lead a study on USA insurances over the period 1989-1999. They show that insurances working in the same country and business line are more inefficient when they make a large capital enhancement. This inefficiency is due to a meaningful over used equity capital. Based on USA property-liability insurances Brockett et al. (2004) show that solvency scores have a restricted affect on efficiency.

Cummins et al. (2006) is the most known study that explores explicitly the link between economic efficiency, financial intermediation and risk management. They investigate the contribution of both activities (risk management and financial intermediation) to the efficiency of the insurance company. They show that shadow prices of these two activities are positives. So, risk management and financial intermediation meaningfully contribute to enhance efficiency. 


\subsection{General level of efficiency and evolution over time}

This field search contains essentially the first application of efficiency methods to countries' insurance companies. Examples of first application studies in some countries: Mansor and Radam (2000) for Malaysia, Chaffai and Ouertani (2002) for Tunisia, Worthington and Hurley (2002) for Australia, Barros and Obijiaku (2007) for Nigeria, etc. The attained results in this field are mixed because the high number of countries and the difference in the employed time period, on which studies investigate. Nevertheless, most studies show the existence of a meaningful inefficiency level that must be eliminated from the studied sample of insurance companies. Noulas et al. (2001) find that Greece insurance companies have an average cost efficiency of 65\%. Yao et al. (2007), studying China insurance industry, find an average technical efficiency of $70 \%$ and $77 \%$, respectively, in life and non life insurance companies.

\subsection{Across-Country Comparisons}

The studies of cross-country comparisons have for advantage to highlight the insurance companies' competitiveness between countries. Nevertheless, these studies are limited to some regions or countries. At the beginning, studies use aggregate economic information Weiss (1991b) and Donni and Fecher (1996). Then, research works are more and more based on individual company data. Rai (1996) uses a data base of 106 insurance companies dispersed in nine European countries, USA and Japan. But this study suffers of its limited database's size. Diacon et al. (2002) concentrate on 15 European countries over the period 1996-1999 and using 450 companies. They find significant across-country differences in average efficiency. The authors conclude that insurances specialized in long term business record the best scores of efficiency. Also, the United Kingdom insurance companies have the lowest levels of allocative and scale efficiency. Fenn et al. (2008) use a database of 14 European countries over the period 1995-2001. They conclude that mergers and acquisition affect positively efficiency in liberalized EU market context. In addition, they find high scores of cost efficiency for the largest insurance companies and those with highest market shares.

\subsection{Market Structure}

The most known papers in this search field are those of Choi and Weiss (2005, 2008). These authors investigate in three theoretical assumptions:

$\checkmark$ "The structure-conduct-performance": the enhancement of market concentration increases prices and profits that encourage firms' collusion.

$\checkmark$ “The relative market power (RMP)": the main idea of this hypothesis is that firms characterized by larger market shares, are considered as leaders in the market. They can use their power for maneuvering market prices.

$\checkmark$ "The efficient structure (ES)": most efficient firms charge the lowest prices compared to their competitors. So, this condition allows them to gain high economic rents as well as market shares.

The efficiency structure hypothesis is confirmed by Choi and Weiss (2005). The authors suggest that more attention must be allocated for efficiency rather than industry consolidation and market power. In the second study, Choi and Weiss (2008) support the relative market power hypothesis. They conclude that insurance companies in competitive and non-strictly regulated states could charge higher prices to profit from their market power.

\subsection{Mergers and Acquisitions}

Mergers and acquisitions is a relatively virgin research area for applying efficiency methods in insurance industry. Kim and Grace (1995) investigate the effect of "hypothetical horizontal mergers" on efficiency of US life insurance companies. They conclude that the majority of mergers usually improve cost efficiency, except for large non life insurance companies. Some studies conclude that 
mergers have a positive effect on both acquiring and target property-liability insurance companies (Cummins et al., 1999; Cummins \& Xie, 2008). More the firm is financially vulnerable more it is risked to be acquired. Similarly to these studies Klumpes (2007) finds, in European insurance market, that requiring firms seems to be more efficient than non-acquiring firms.

\subsection{Corporate Governance and Organizational Forms}

Several studies focus on the effect of corporate governance and organizational form on firms' efficiency. The two key hypotheses in this field search are: the managerial discretion hypothesis and the expense preference hypothesis proposed, relatively, by Mayers and Smith (1988) and Mester (1991). For The first hypothesis, Cummins and Weiss (2000) show that stock companies and mutual insurers don't share the same technology. The authors find that mutual companies are characterized by a lower managerial discretion and more efficient in lines of business compared to stock companies. The second hypothesis affirms that stock companies are more efficient than mutual insurers, due to the privileges allocated to mutual managers. The empirical tests of the two hypotheses presented above leads to non-conclusive results. Many studies found that stock companies are least efficient than mutual insurers. Diacon et al. (2002) find lower scores of technical efficiency for stock companies than for mutual insurers, for a sample dispersed in 15 European countries. Using a sample of USA life insurance companies, Greene and Segal (2004) show that the two organizational forms are similarly cost efficient. However, other studies conclude that mutual companies are least efficient than stock companies, thus validating the expense preference hypothesis (Cummins et al., 1999; Diboky \& Ubl, 2007; Erhemjamts \& Leverty, 2007). Other studies in this search field, focus on the efficiency progress after a demutualization or when comparing private firms versus initial public offerings (Jeng et al., 2007; \& Xie, 2008). Hard-wick et al. (2004) study the relation between the size of the board of directors and cost efficiency.

\subsection{Regulation issues}

The financial sector deregulation enhances competition between firms improving both market efficiency and consumer choice. Nevertheless, there is no theoretical consensus about the effect of deregulation on efficiency gains. Rees et al. (1999) study the life insurance markets of the UnitedKingdom and Germany over the period 1992-1994. The authors conclude that deregulation slightly improves efficiency of life insurance companies. Mahlberg (2000) leads a study on life and non-life Germany insurance companies over the period 1992-1996. He shows that deregulation decreases efficiency, but it enhances productivity. Boonyasai et al. (2002) conclude that deregulation enhances productivity in Korea and Philippines. Noting that Hussels and Ward (2006) show there is no clear evidence for the relation between deregulation and efficiency.

\section{Conclusion}

This section is a theoretical background of efficiency concept in general and particularly its different applications in insurance industry. The first sub-section is focused on the theoretical foundation of efficiency. So we have presented the pioneer of this concept, its different aspects such as Scale economies, scope economies, and X-efficiency. The X-efficiency measurement is based on some objective functions namely: cost function, revenue function, profit function and production technology presented by the directional output distance function.

The second sub-section investigates different techniques developed in the literature to estimate the frontier and measure efficiency. There are two principal approaches the non parametric approach and the econometric approach. The first approach also called the mathematical programming approach contain two methods the Data Envelopment Analysis (DEA) and the Free Disposable Hull (FDH). The second approach also called parametric approach contains three principal methods the thick frontier approach (TFA), stochastic frontier approach (SFA) and the distribution-free approach 
(DFA). Finally, the last sub-section represents an overview of efficiency investigations in insurance industry. In this part we have presented some principal research fields in which efficiency is investigated in insurance industry: Agent Distribution Systems, Capital Exploitation and Financial Risk Management, General level of efficiency and evolution over time, Across-Country Comparisons, Market Structure, Mergers and Acquisitions, Corporate Governance and Organizational Forms, Regulation issues...

\section{References}

Aigner, D., Lovel, C, \& Schmidt, P. (1977). Formulation and estimation of stochastic frontier production function models. Journal of Econometrics, 6, 21-37.

Barros, P., Barroso, N., \& Borges, M. R. (2005). Evaluating the efficiency and productivity of insurance companies with a Malmquist index: A case study for Portugal. Geneva Papers on Risk and Insurance, 30 (2), 244-267.

Barros, P., \& Obijiaku, E. L. (2007). Technical efficiency of Nigerian insurance companies. Department of Economics, Institute for Economics and Business Administration (ISEG), Technical University of Lisbon. Working Papers No. 18.

Berger, A. N., Cummins, J. D., Weiss, M. A., \& Zi, H. (2000). Conglomeration versus strategic focus: Evidence from the insurance industry. Journal of Financial Intermediation, 9 (4), 323362.

Berger, A. N., Bonime S. D., Covitz D. M., \& Hancock. D. (2000). Why are bank profits so persistent? The roles of product market competition, informational opacity, and regional/macroeconomic shocks. Journal of Banking and Finance, 24 (7), 1203-1235.

Berger, A. N., Cummins, J. D., \& Weiss, M. A. (1997). The coexistence of multiple distribution systems for financial services: The case of property-liability insurance. Journal of Business, 70 (4), 515-546.

Berger, A. N., Cummins, J. D., Weiss, M. A., \& Zi, H. (2000). Conglomeration Versus Strategic Focus: Evidence from the Insurance Industry. Journal of Financial Intermediation 9 (4), 323-362.

Berger, A. N., \& Mester, L. J. (1997). Inside the black box: What explains differences in the efficiencies of financial institutions? Journal of Banking and Finance, 21, 895-947.

Berger, A.N, Humphrey, D.B., \& Pulley, L.B. (1996). Do consumers pay for one-stop banking? Evidence from an alternative revenue function. Journal of Banking and Finance, 20(9), 16011621.

Berger. A, \& Humphrey. D. (1997). Efficiency of financial institutions: International survey and direction of future research. European Journal of Operational Research, 98, 175-212.

Berger, A. N, Bonime, S. D., Covitz, D. M., \& Hancock, D. (2000). Why are bank profits so persistent? The roles of product market competition, informational opacity, and regional/macroeconomic shocks. Journal of Banking and Finance, 24(7), 1203-1235.

Boonyasai, T., Grace, M. F., \& Skipper, Jr., H. D. (2002). The effect of liberalization and deregulation on life insurer efficiency. Working Paper No. 02-2, Center for Risk Management and Insurance Research, Georgia State University, Atlanta.

Brockett, P. L., Cooper, W. W., Golden, L. L., Rousseau, J. J., \& Wang, Y. (1998). DEA evaluations of the efficiency of organizational forms and distribution systems in the US property and liability insurance industry. International Journal of Systems Science, 29 (11), 1235-1247.

Brockett, P. L., Cooper, W. W., Golden, L. L., Rousseau, J. J., \& Wang, Y. (2004). Evaluating solvency versus efficiency performance and different forms of organization and marketing in US property-liability insurance companies. European Journal of Operational Research, 154 (2), $492-$ 514.

Carr, R. M., Cummins, J. D., \& Regan, L. (1999). Efficiency and competitiveness in the US life insurance industry: Corporate, product, and distribution strategies. In: Cummins, J. D., Santomero, A. M., eds., Changes in the Life Insurance Industry: Efficiency, Technology and Risk Management. Kluwer Academic Publishers, Boston, MA. 
Casu. B., \& Molyneux, P. (2003). A comparative study of efficiency in European banking. United Kingdom: University of Wales.

Chaffai, M. E., \& Ouertani, M. N. (2002). Technical efficiency in the Tunisian insurance industry: A comparison of parametric and non parametric time variant models. Working Paper, Research Unit on Production Econometrics, Sfax University, Sfax.

Chaffai, M. E., \& Ouertani, M. N. (2002). Technical efficiency in the Tunisian insurance industry: A comparison of parametric and non parametric time variant models. Working Paper, Research Unit on Production Econometrics, Sfax University, Sfax.

Chambers, R. G, Chung, Yangho, Färe, Rolf (1996). Benefit and Distance Functions. Journal of Economic Theory. Vol. 70 (2). pp. 407-19. August 1996.

Chambers, Robert G, Chung, Yangho, Färe, Rolf (1998a), "Profit, Directional Distance Functions, and Nerlovian Efficiency," Journal of Optimization Theory and Applications, Volume 98, No. 2, 351-364, August, 1998.

Charnes, A., Cooper, W. W., Rhodes, E., 1978. Measuring the Efficiency of Decision Making Units. European Journal of Operational Research 2 (6), 429-444.

Choi, P. B., Weiss, M. A., 2005. An Empirical Investigation of Market Structure, Efficiency, and Performance in Property-Liability Insurance. Journal of Risk and Insurance 72 (4), 635-673.

Choi, P. B., Weiss, M. A., 2005. An Empirical Investigation of Market Structure, Efficiency, and Performance in Property-Liability Insurance. Journal of Risk and In-surance 72 (4), 635-673.

Choi, P. B., Weiss, M. A., 2008. State regulation and the structure, conduct, efficiency and performance of US auto insurers. Journal of Banking and Finance 32 (2008), 134-156.

Choi, P. B., Weiss, M. A., 2008. State regulation and the structure, conduct, efficiency and performance of US auto insurers. Journal of Banking and Finance 32 (2008), 134-156.

Choi, P. B., Weiss, M. A., 2008. State regulation and the structure, conduct, efficiency and performance of US auto insurers. Journal of Banking and Finance 32 (2008), 134-156.

Chung, Y., Färe, R., Grosskopf, S., 1997. Productivity and undesirable outputs: a directional distance function approach. Journal of Environmental Management 51, 229-240.

Cummins, J. D., M. A. Weiss, and H. Zi,2003, Economies of Scope in Financial Services: A Dea Bootstrapping Analysis of the U.S. Insurance Industry, Working Paper, Wharton financial Institutions Center.

Cummins, J. D., Weiss, M. A., \& Zi, H. (2007). Economics of scope in financial services: A DEA bootstrapping analysis of the US insurance industry. Working Paper, the Wharton School, Philadelphia, PA.

Cummins, J. David, and Mary A. Weiss, 2000. Analyzing Firm Performance in the Insurance Industry Using Frontier Efficiency and Productivity methods, in Georges Dionne, ed.: Handbook of Insurance (Norwell, MA: Kluwer Academic Publishers).

Cummins, J. D., Nini, G. P., 2002. Optimal Capital Utilization by Financial Firms: Evidence from the Property-Liability Insurance Industry. Journal of Financial Services Research 21 (1-2), 15-53.

Cummins, J. D., Weiss, M. A., 2000. Analyzing Firm Performance in the Insurance Industry Using Frontier Efficiency Methods. In: Dionne, G., ed., Handbook of Insurance Economics. Kluwer Academic Publishers, Boston, MA.

Cummins, J. D., \& Weiss, M. A. (2000). Analyzing ?rm performance in the insurance industry using frontier efficiency and productivity methods. In: Dionne, Georges (Ed.), Handbook of Insurance. Kluwer Academic Publishers, Norwell, MA.

Cummins, J. D., \& Xie, X. (2008). Mergers and acquisitions in the US property-liability insurance industry: Productivity and efficiency effects. Journal of Banking and Finance, 32 (1), 30-55.

Cummins, J. D., 1999. Efficiency in the US Life Insurance Industry: Are Insurers Mi-nimizing Costs and Maximizing Revenues? In: Cummins, J. D., Santomero, A. M., eds., Changes in the Life Insurance Industry: Efficiency, Technology and Risk Management. Kluwer Academic Publishers, Boston, MA. 
Cummins, J. D., 1999. Efficiency in the US Life Insurance Industry: Are Insurers Minimizing Costs and Maximizing Revenues? In: Cummins, J. D., Santomero, A. M., eds., Changes in the Life Insurance Industry: Efficiency, Technology and Risk Management. Kluwer Academic Publishers, Boston, MA.

Cummins, J. D., Dionne, G., Gagné, R., Nouira, A., 2006. Efficiency of Insurance Firms with Endogenous Risk Management and Financial Intermediation Activities. Working Paper.

Cummins, J. D., Nini, G. P., 2002. Optimal Capital Utilization by Financial Firms: Evidence from the Property-Liability Insurance Industry. Journal of Financial Ser-vices Research 21 (1-2), 15-53.

Cummins, J. D., Rubio-Misas, M., Zi, H., 2004. The Effect of Organizational Structure on Efficiency: Evidence from the Spanish Insurance Industry. Journal of Banking and Finance 28 (12), 31133150.

Cummins, J. D., Tennyson, S., \& Weiss, M. A. (1999). Consolidation and efficiency in the US life insurance industry. Journal of Banking and Finance, 23 (2-4), 325-357.

Cummins, J. D., Turchetti, G., \& Weiss, M. A. (1996). Productivity and technical efficiency Italian insurance industry. Working Paper, Wharton Financial Institutions Center, University of Pennsylvania, PA.

Cummins, J. D., \& Weiss, M. A. (1993). Measuring cost efficiency in the property-liability insurance industry. Journal of Banking and Finance, 17(2-3), 463-481.

Cummins, J. D., \& Weiss, M. A. (2000). Analyzing Firm Performance in the Insurance Industry Using Frontier Efficiency Methods. In: Dionne, G., ed., Handbook of Insurance Economics. Kluwer Academic Publishers, Boston, MA.

Cummins, J. D., Weiss, M. A., \& Zi, H. (1999). Organizational form and efficiency: The coexistence of stock and mutual property-liability insurers. Management Science, 45 (9), 1254-1269.

Cummins, J. D., \& Xie, X. (2008). Mergers and acquisitions in the US property-liability insurance industry: Productivity and efficiency effects. Journal of Banking and Finance, 32 (1), 30-55.

Cummins, J. D., \& Zi, H. (1998). Comparison of frontier efficiency methods: An application to the US life insurance industry. Journal of Productivity Analysis, 10(2), 131-152.

Debreu, G. (1951). The coefficient of resource utilization. Econometrica, 19, 273-292.

Deprins, D., Simar, L., \& Tulkens, H. (1984). Measuring labor-efficiency in post offices, The performance of public enterprises: concepts and measurement. Amsterdam: North Holland.

DeYoung. R., \& Nolle, D. E. (1996). Foreign-owned banks in the United States: Earning market share or buying it?. Journal of Money, Credit and Banking, 28(4), Part 1: 622-636.

Diacon, S. R., Starkey, K., \& O’Brien, C. (2002). Size and efficiency in European long-term insurance companies: An international comparison. Geneva Papers on Risk and Insurance, 27 (3), 444-466.

Diboky, F., \& Ubl, E. (2007). Ownership and efficiency in the German life insurance market: A DEA Bootstrap Approach. Working Paper.

Donni, O., \& Fecher, F. (1997). Efficiency and productivity of the insurance industry in the OECD countries. Geneva Papers on Risk and Insurance, 22 (84), 523-535.

Eling, M., \& Luhnen, M. (2010), Efficiency in the international insurance industry: A cross-country comparison. Journal of Banking and Finance, 34(7), 1497-1509.

Ennsfellner, K. C., Lewis, D., \& Anderson, R. I. (2004). Production efficiency in the Austrian insurance industry: A Bayesian examination. Journal of Risk and Insurance, 71 (1), 135-159.

Erhemjamts, O., \& Leverty, J. T. (2007). The demise of the mutual organizational form: An investigation of the life insurance industry. Working Paper.

Farrell, M. J. (1957). The measurement of productive efficiency. Journal of the Royal Statistical Society, 120, 253-81.

Fecher, F., Kessler, D., Perelman, S., \& Pestleau, P. (1993). Productive performance in the French insurance industry. Journal of Productivity Analysis, 77-93.

Fecher, F., Perelman, S., \& Pestieau, P. (1991). Scale economics and performance in the French insurance industry. Geneva Papers on Risk and Insurance, 16 (60), 315-326. 
Fenn, P., Vencappa, D., Diacon, S., Klumpes, P., \& O’Brien, C. (2008). Market structure and the efficiency of European insurance companies: A stochastic frontier analysis. Journal of Banking and Finance, 32 (1), 86-100.

Färe, R., Grosskopf, S., Lovell, C.A.K., \& Pasurka, C. (1989)/ Multilateral productivity comparisons when some outputs are undesirable: a nonparametric approach. The Review of Economics and Statistics, 71, 90-98.

Färe, R., \& Primont, D. (1995). Multi-output Production and Duality: Theory and Applications. Kluwer Academic Publisher, Boston, Massachusetts, 1995.

Fuentes, H., Grifell-Tatjé, E., \& Perelman, S. (2005). Product specialization, efficiency and productivity change in the Spanish insurance industry. Working Paper, Université de Liège.

Gardner, L. A., \& Grace, M. F. (1993). X-efficiency in the U.S. life insurance industry. Journal of Banking and Finance, 17 (April), 497-510.

Gardner, L. A., \& Grace, M. F. (1993). X-Efficiency in the US life insurance industry. Journal of Banking and Finance, 17 (2-3), 497-510.

Greene, W. H., \& Segal, D. (2004). Profitability and efficiency in the US Life insurance industry. Journal of Productivity Analysis, 21 (3), 229-247.

Griffel Tatjé, E., \& Lovell, C.A. K. (1997). The Sources of productivity Change in Spanish Banking. European Journal of Operational Research, 98 (2), 364-380.

Hancock, D. (1985). The financial firm: Production with monetary and non-monetary goods. Journal of Political Economy, 93 (5), 859-880.

Hao, J. C. J. (2007). Efficiency test on Taiwan's life insurance industry-using x-efficiency approach. Information and Management Sciences, 18 (1), 37-48.

Hao, J. C. J., \& Chou, L. Y. (2005). The estimation of efficiency for life insurance industry: The case in Taiwan. Journal of Asian Economics, 16 (5), 847-860.

Hardwick, P. (1997). Measuring cost inefficiency in the UK life insurance industry. Applied Financial Economics, 7 (1), 37-44.

Hardwick, P., Adams, M., \& Zou, H. (2004). Corporate Governance and Cost Efficiency in the United Kingdom Life Insurance Industry. Working Paper.

Hughes, J.P., \& Mester, L.J. (1998). Bank capitalization and cost: evidence of scale economies in risk management and signaling. Review of Economics and Statistics, 80, 314-325.

Hussels, S., \& Ward, D. R. (2006). The impact of deregulation on the German and UK life insurance markets: An analysis of efficiency and productivity between 1991-2002. Working Paper, Cranfield Research Paper Series (4).

Hwang, T., \& Gao, S. S. (2005). An empirical study of cost efficiency in the Irish life insurance industry. International Journal of Accounting, Auditing and Performance Evaluation, 2 (3), 264 280.

Ikhide, S. (2000). Efficiency of commercial banks in Namibia. Occasional Paper 4. Namibia: Bank of Namibia.

Jeng, V., Lai, G. C., \& McNamara, M. J. (2007). Efficiency and demutualization: Evidence from the US life insurance industry in the 1980s and 1990s. Journal of Risk and Insurance 74 (3), 683-711.

Kim, H., \& Grace, M. F. (1995). Potential ExPost efficiency gains of insurance company mergers. Working Paper, Center for RMI Research 95-4, College of Business Administration, Georgia State University, Atlanta.

Klumpes, P. J. M. (2004). Performance Benchmarking in Financial Services: Evidence from the UK Life Insurance Industry. Journal of Business, 77 (2), 257-274.

Koopmans, T.C. (1951). An analysis of production as an efficient combination of activities. In: Koopmans TC, editor. Activity Analysis of production and allocation. New York: Wiley.

Leibenstein, H. (1966). Allocative efficiency versus X-efficiency. American Economic Review, 56, 392-415.

Luenberger, D. G. (1995). Microeconomic Theory. McGraw-Hill, New York, New York. 
Luenberger, D.G. (1992). New optimality principles for economic efficiency and equilibrium. Journal of Optimization Theory and Applications, 75, 221-264.

Mahlberg, B. (2000). Technischer Fortschritt und Produktivitätsveränderungen in der deutschen Versicherungswirtschaft. Jahrbücher für Nationalökonomik und Statistik 220 (5).

Mansor, S. A., \& Radam, A. (2000). Productivity and efficiency performance of the Malaysian life insurance industry. Jurnal Ekonomi Malaysia 34, 93-105.

Mayers, D., \& Smith, C. W. (1988). Ownership structure across lines of property-casualty insurance. Journal of Law and Economics, 31, 351-378.

Meador, J. W., Ryan, Jr., H. E., \& Schellhorn, C. D. (2000). Product focus versus diversification: Estimates of $x$-efficiency for the US life insurance industry. Working Paper, Wharton Financial Institutions Center University of Pennsylvania.

Meador, J. W., Ryan, Jr., H. E., \& Schellhorn, C. D. (2000). Product focus versus diversification: estimates of X-efficiency for the US life insurance industry. Working Paper, Wharton Financial Institutions Center University of Pennsylvania.

Meeusen, W., \& Broeck, J. (1977). Efficiency estimation for Cobb Douglas production functions with composed Error. International Economic Review, 18 (2), 435444.

Mester, L. J. (1991). Agency costs among savings and loans. Journal of Financial Intermediation, 1, 257-278.

Noulas, A. G., Hatzigayios, T., Lazaridis, J., \& Lyroudi, K. (2001). Non-parametric production frontier approach to the study of efficiency of non-life insurance companies in Greece. Journal of Financial Management and Analysis, 14 (1), 19-26.

Chambers, R.G., Chung, Y.H., \& Färe, R. (1996). Benefit and distance functions. Journal of Economic Theory, 70, 407-419.

Rai, A. (1996). Cost efficiency of international insurance firms. Journal of Financial Services Research, 10(3), 213-233.

Rees, R., Kessner, E., Klemperer, P., \& Matutes, C. (1999). Regulation and efficiency in European insurance markets. Economic Policy, 14(29), 363-397.

Ryan, Jr., H. E., \& Schellhorn, C. D. (2000). Life insurer cost efficiency before and after implementation of the NAIC risk-based capital standards. Journal of Insurance Regulation, 18 (3), 362-384.

Shephard, R.W. (1953). Cost and production functions. Princeton University Press, Princeton.

Shephard, R. W. (1974). Indirect production functions. Mathematical Systems in Economics, 10, Meisenheirm am Glan: Verlag Anton Hain.

Shephard, R.W. (1970). The theory of cost and production functions. Princeton University Press, Princeton.

Toivanen, O. (1997). Economies of scale and scope in the Finnish non-life insurance industry. Journal of Banking and Finance, 21(6), 759-779.

Ward, D. (2002). The costs of distribution in the UK life insurance market. Applied Economics, 34 (15), 1959-1968.

Weiss, M. A. (1991b). International P/L insurance output, input, and productivity comparisons. Geneva Papers on Risk and Insurance Theory, 16 (2), 179-200.

Worthington, A. C., \& Hurley, E. V. (2002). Cost efficiency in Australian general Insurers: A nonparametric approach. The British Accounting Review, 34(2), 89-108.

Xie, X. (2008). Are publicly held firms less efficient? Evidence from the US property-liability insurance industry. Working Paper.

Yao, S., Han, Z., \& Feng, G. (2007). On the technical efficiency of China's insurance industry after WTO accession. China Economic Review, 18(1), 66-86.

Yuengert, A. M. (1993). The measurement of efficiency in life insurance: Estimates of a mixed normal-gamma error model. Journal of Banking and Finance, 17 (2-3), 483-496. 